\title{
Opposing Synaptic Regulation of Amyloid- $\beta$ Metabolism by NMDA Receptors In Vivo
}

\author{
Deborah K. Verges, ${ }^{1}$ Jessica L. Restivo, ${ }^{1}$ Whitney D. Goebel, ${ }^{1}$ David M. Holtzman, ${ }^{1,2,3,4}$ and John R. Cirrito ${ }^{1,3,4}$ \\ Departments of ${ }^{1}$ Neurology and ${ }^{2}$ Developmental Biology, ${ }^{3} \mathrm{Hope}$ Center for Neurological Disorders, and ${ }^{4}$ Knight Alzheimer's Disease Research Center, \\ Washington University School of Medicine, St. Louis, Missouri 63110
}

The concentration of amyloid- $\beta(\mathrm{A} \beta)$ within the brain extracellular space is one determinant of whether the peptide will aggregate into toxic species that are important in Alzheimer's disease (AD) pathogenesis. Some types of synaptic activity can regulate A $\beta$ levels. Here we demonstrate two distinct mechanisms that are simultaneously activated by NMDA receptors and regulate brain interstitial fluid (ISF) A $\beta$ levels in opposite directions in the living mouse. Depending on the dose of NMDA administered locally to the brain, ISF A $\beta$ levels either increase or decrease. Low doses of NMDA increase action potentials and synaptic transmission which leads to an elevation in synaptic $\mathrm{A} \beta$ generation. In contrast, high doses of NMDA activate signaling pathways that lead to ERK (extracellular-regulated kinase) activation, which reduces processing of APP into A $\beta$. This depression in A $\beta$ via APP processing occurs despite dramatically elevated synaptic activity. Both of these synaptic mechanisms are simultaneously active, with the balance between them determining whether ISF A $\beta$ levels will increase or decrease. NMDA receptor antagonists increase ISF A $\beta$ levels, suggesting that basal activity at these receptors normally suppresses $\mathrm{A} \beta$ levels in vivo. This has implications for understanding normal $\mathrm{A} \beta$ metabolism as well as $\mathrm{AD}$ pathogenesis.

\section{Introduction}

Aggregation of amyloid- $\beta(\mathrm{A} \beta)$ as soluble oligomers and insoluble plaques is central to the pathogenesis of Alzheimer's disease (Hardy, 2006). The concentration of monomeric soluble $A \beta$ is a critical factor determining whether and when $\mathrm{A} \beta$ will form these toxic multimers (Lomakin et al., 1997). Thus, understanding the mechanisms that regulate $\mathrm{A} \beta$ levels has implications for understanding disease pathogenesis, as well as developing anti- $\mathrm{A} \beta$ therapies. Amyloid plaques exist within the brain extracellular space. While the initial seed of a plaque may form intracellularly or extracellularly (Gouras et al., 2000; Meyer-Luehmann et al., 2003), it appears that soluble $A \beta$ within the extracellular fluid, or interstitial fluid, contributes to plaque growth (Yan et al., 2009). Numerous studies have elucidated the mechanisms by which amyloid precursor protein (APP) is cleaved by $\beta$-secretase and $\gamma$-secretase to produce $\mathrm{A} \beta$ (for review, see Zhang et al., 2011); however, the mechanisms that regulate how much $\mathrm{A} \beta$ is produced are only partly understood.

Recent studies demonstrate that synaptic activity is a key regulator of A $\beta$ generation (Kamenetz et al., 2003). Seizures in APP transgenic mice rapidly increase brain interstitial fluid (ISF) $\mathrm{A} \beta$

\footnotetext{
Received Feb. 3, 2011; revised June 12, 2011; accepted June 14, 2011

Author contributions: D.K.V., D.M.H., and J.R.C. designed research; D.K.V., J.L.R., W.D.G., and J.R.C. performed research; J.L.R., W.D.G., and J.R.C. analyzed data; J.R.C. wrote the paper.

We thank the National Institutes of Health/NIA (K01 AG029524 and P50 AG568127 to J.R.C.), the Shmerler family (J.R.C.), the Charles F. and Joanne Knight Alzheimer's Disease Research Center at Washington University (J.R.C.), the McDonnell Center for Cell and Molecular Biology (J.R.C.), Cure Alzheimer's Fund (D.M.H.), and Elison Medical Foundation (D.M.H.).

The authors declare no competing financial interests.

Correspondence should be addressed to John R. Cirrito, Department of Neurology, Washington University School of Medicine, St. Louis, M0 63110. E-mail: cirritoj@neuro.wustl.edu.

DOI:10.1523/JNEUROSCI.0607-11.2011

Copyright $\odot 2011$ the authors $\quad 0270-6474 / 11 / 3111328-10 \$ 15.00 / 0$
}

levels, whereas blocking neuronal activity with tetrodotoxin (TTX) reduces $A \beta$ levels (Cirrito et al., 2005). Synaptic activity leads to elevated clathrin-mediated endocytosis at the presynaptic terminal, which increases APP internalization and subsequent $\mathrm{A} \beta$ generation by $\beta$-secretase and $\gamma$-secretase within endosomes (Cirrito et al., 2008). A portion of the synaptically generated $A \beta$ is then secreted at the axon terminal (Wei et al., 2010), which is capable of aggregating and forming $\mathrm{A} \beta$ plaques (Harris et al., 2010). The above studies are consistent with a synaptic mechanism that directly leads to $A \beta$ generation and release from neurons.

Second messenger signaling pathways that are induced by neurotransmitter receptors can alter APP processing and therefore alter $A \beta$ production. For instance, muscarinic acetylcholine receptors activate protein kinase $\mathrm{C}$, which increases $\alpha$-secretase cleavage of APP, thus reducing $\mathrm{A} \beta$ levels in animal models and humans (Nitsch et al., 2000; Hock et al., 2003; Caccamo et al., 2006; Davis et al., 2010). NMDA receptors (NMDA-Rs) can also modulate $A \beta$ levels. In addition to NMDA-Rs inducing synaptic plasticity, they also cause nonamyloidogenic processing of APP (Fazeli et al., 1994). Activation of these receptors increases $\alpha$-secretase localization at synapses and reduces $\mathrm{A} \beta$ production (Gordon-Krajcer et al., 2002; Marcello et al., 2007). Depending on the culture system used, some studies have found NMDA-Rs to either increase or decrease $\mathrm{A} \beta$ levels (Lesné et al., 2005; Hoey et al., 2009).

Our studies in living mice demonstrate that NMDA-Rs can either increase or decrease ISF $A \beta$ levels depending on the level of receptor activation. Low doses of NMDA elevate ISF A $\beta$ levels by increasing synaptic transmission and subsequent $A \beta$ generation, whereas high doses of NMDA depress $A \beta$ by activating synapticdependent signaling cascades that reduce amyloidogenic pro- 
A

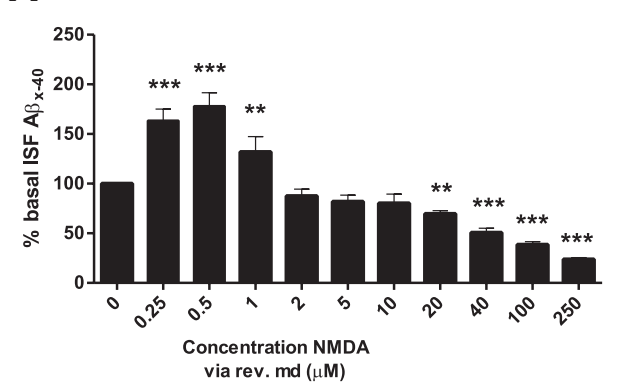

C

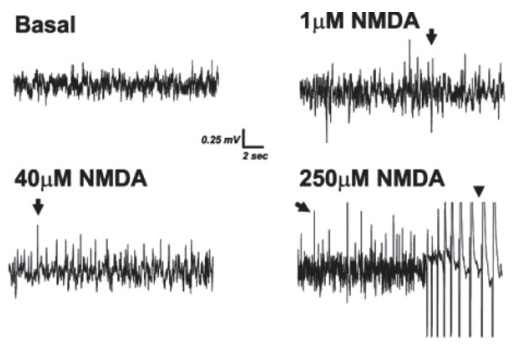

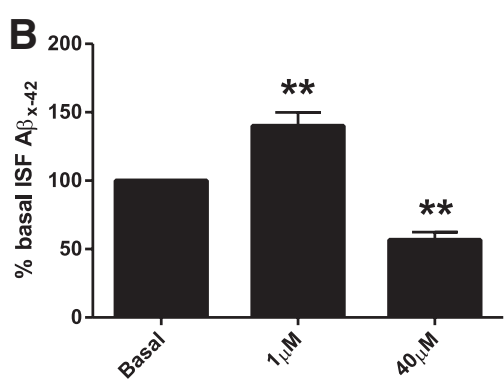

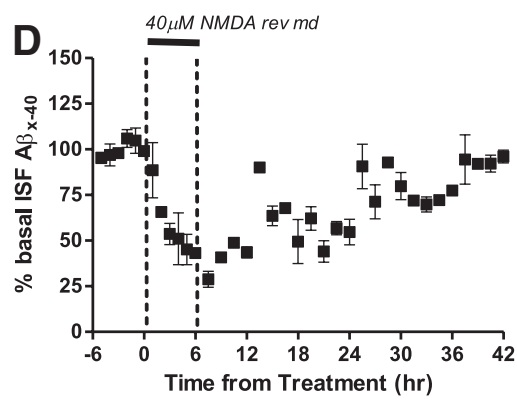

Figure 1. Differential dose-dependent effect of NMDA-R signaling on ISF A $\beta$ levels in vivo. $\boldsymbol{A}$, Direct NMDA infusion into the brain via reverse microdialysis caused a differential dose-dependent change in ISF $A \beta$ levels. Mean $A \beta$ concentrations during hours $2-3$ of a total $3 \mathrm{~h}$ treatment at each dose. At NMDA doses of $0.25-1 \mu \mathrm{M}$, there were significant increases in ISF $A \beta_{40}$ with a $32 \pm 15.2 \%$ elevation at $1 \mu \mathrm{m}$ compared to basal levels $(p<0.01)$. At NMDA doses of $20-250 \mu \mathrm{m}$, there was a dose-dependent decrease in ISF $A \beta_{40}$ levels. Forty micromolar NMDA reduced $A \beta_{40}$ levels by $49.3 \pm 4.3 \%$ with a maximal depression of $76.2 \pm$ $1.8 \%$ at $250 \mu$ M NMDA. $n=6-10$ per dose. $B$, A subset of mice also had $A \beta_{42}$ levels assessed during NMDA infusion. One and forty micromolar NMDA altered $A \beta_{42}$ levels by increasing $40.0 \pm 9.9 \%(p<0.01)$ and decreasing $43.3 \pm 5.7 \%(p<0.01)$, respectively ( $n=6$ per group). C, Representative EEG trace from a PS1APP ${ }^{+/-}$administered escalating doses of NMDA by reverse microdialysis. EEG activity recorded within the hippocampus showed synchronous spikes in activity at 1 and $40 \mu \mathrm{M}$ NMDA (arrows) and intermittent epileptiform activity at $250 \mu \mathrm{M}$ NMDA (arrowhead). D, Forty micromolar NMDA was administered to the hippocampus for $6 \mathrm{~h}$ and then removed from the microdialysis perfusion buffer. During the next $30 \mathrm{~h}$ of sampling, ISF A $\beta$ levels gradually returned to baseline levels; $94.3 \pm 13.5 \%$ compared to basal levels in each mouse $(n=5) .{ }^{* *} p<0.01,{ }^{* * *} p<0.001$.

cessing of APP. The balance between these mechanisms within a single cell and within neuronal networks will determine whether NMDA-Rs increase or decrease $\mathrm{A} \beta$ in vivo.

\section{Materials and Methods}

Animals. All experimental procedures involving animals were performed in accordance with guidelines established by the Animal Studies Committee at Washington University. We bred APP/PS1 $1 E 9$ (PS1APP) hemizygous mice (The Jackson Laboratory) (Savonenko et al., 2003) to wild-type $\mathrm{C} 3 \mathrm{H} / \mathrm{B} 6$ mice, and then aged the PS1APP ${ }^{+/-}$offspring to 2.5-3.5 months for use in experiments. Animals were screened for the PS1APP transgenes by PCR from tail DNA. Three-month-old C57BL6 mice were ordered directly from The Jackson Laboratory for use in experiments. An equal number of males and females were used in each experiment.

Compounds. All pharmacological agents were purchased from SigmaAldrich unless otherwise noted. The NMDA-receptor antagonist 3-(2carboxypiperazin-4-yl)propyl-1-phosphonic acid (CPP) was diluted into saline and administered intraperitoneally at $20 \mathrm{mg} / \mathrm{kg}$. FR180204, PD98059, and ifenprodil were purchased from Tocris Bioscience.

In vivo microdialysis. In vivo microdialysis to assess brain ISF A $\beta$ in the hippocampus of awake, freely moving PS1APP mice was performed similarly to previously described (Cirrito et al., 2003, 2005, 2008). This technique samples soluble molecules within the extracellular fluid that are smaller than $30 \mathrm{kDa}$, the molecular-weight cutoff of the probe membrane. $\mathrm{A} \beta$ capable of entering the probe, likely to be predominantly monomeric $\mathrm{A} \beta$, has been dubbed "exchangeable $\mathrm{A} \beta$ " or "eA $\beta$ " (Cirrito et al., 2003).

Under isoflurane volatile anesthetic, guide cannula (BR-style, Bioanalytical Systems) were cemented into the left hippocampus (bregma $-3.1 \mathrm{~mm}, 2.5 \mathrm{~mm}$ lateral to midline, and $1.2 \mathrm{~mm}$ below dura at a $12^{\circ}$ angle). Two-millimeter microdialysis probes were inserted through the guides so the membrane was contained entirely within the hippocampus (BR-2, $30 \mathrm{kDa}$ MWCO membrane, Bioanalytical Systems). Microdialysis perfusion buffer was artificial CSF (in $\mathrm{mm}$ : $1.3 \mathrm{CaCl}_{2}, 1.2 \mathrm{MgSO}_{4}, 3 \mathrm{KCl}, 0.4 \mathrm{KH}_{2} \mathrm{PO}_{4}, 25$ $\mathrm{NaHCO}_{3}$, and $122 \mathrm{NaCl}$, pH 7.35) containing $4 \%$ bovine serum albumin that was filtered through a $0.1 \mu \mathrm{m}$ membrane. For studies infusing BAPTA-AM via reverse microdialysis, the microdialysis perfusion buffer had calcium replaced with magnesium. Flow rate was a constant $1.0 \mu \mathrm{l} / \mathrm{min}$. Samples were collected every $60-90 \mathrm{~min}$ with a refrigerated fraction collector into polypropylene tubes and assessed for $\mathrm{A} \beta_{x-40}$ or $\mathrm{A} \beta_{x-42}$ by sandwich ELISA at the completion of each experiment. Basal levels of ISF A $\beta$ were defined as the mean concentration of $\mathrm{A} \beta$ over $6 \mathrm{~h}$ preceding drug treatment. Once basal ISF A $\beta$ levels were established, PS1APP mice were treated with a variety of compounds by reverse microdialysis or by intraperitoneal injection. For each animal, all ISF A $\beta$ levels were normalized to the basal $\mathrm{A} \beta$ concentration for that mouse. Experiments took place under constant light conditions. Mouse ISF $\mathrm{A} \beta$ levels fluctuate in a diurnal rhythm if mice are allowed to recover for 2 weeks after microdialysis cannula placement and exposed to 2 weeks of a $12 \mathrm{~h} / 12 \mathrm{~h}$ light/dark cycle before assessment of ISF A $\beta$ (Kang et al., 2009). However, under constant light conditions without entraining mice to a 12 $\mathrm{h} / 12 \mathrm{~h} \mathrm{light/dark}$ cycle after microdialysis cannula placement, ISF $A \beta$ levels fluctuate hourly by only $10-15 \%$ over a $3 \mathrm{~d}$ period.

Compounds delivered to the hippocampus via reverse microdialysis were diluted in microdialysis perfusion buffer, which consisted of artificial CSF with $4 \%$ bovine serum albumin. Several compounds were delivered to the brain using reverse microdialysis. With this approach, determining the absolute concentrations of a compound within the brain is difficult because of differences in efflux from the probe, diffusion within the brain, and compound pharmacokinetics; therefore, only the starting concentration of each compound is reported.

For the NMDA dose escalation study (Fig. 1A), each dose of compound was administered for $3 \mathrm{~h}$ in ascending fashion. One group of mice received doses from $0.25-10 \mu \mathrm{M}$ and another group received doses ranging from 5 to $250 \mu \mathrm{M}$ NMDA. When delivered in this fashion, we grossly estimate that the dose achieved within the brain is $50 \%$ of the actual concentration within the microdialysis perfusion buffer.

Murine ISF $\mathrm{A} \beta_{40}$ levels in wild type were assessed using a similar protocol as PS1APP mice, except longer sample times of $6 \mathrm{~h}$ at a 0.5 $\mu \mathrm{l} / \mathrm{min}$ flow rate were necessary to concentrate ISF samples. For each mouse, the basal concentration of $\mathrm{A} \beta$ was established over a single $6 \mathrm{~h}$ collection followed by two $6 \mathrm{~h}$ collections during treatment with either 1 $\mu \mathrm{M}$ NMDA, $40 \mu \mathrm{M}$ NMDA, or CPP.

EEG recording. To record EEG activity, bipolar recording electrodes (Teflon-coated, platinum-iridium wire, 0.0055 inch coated OD, A-M Systems) were attached to the shaft of the microdialysis guide cannula with Elmer's Super-Fast Epoxy Resin (Elmer's). Electrodes extended $\sim 1$ $\mathrm{mm}$ from the tip of the guide, so that the electrode tip was located at the center of the $2 \mathrm{~mm}$ microdialysis membrane. EEG activity was assessed using a P511K A.C. Preamplifier (Grass Instruments), digitized with a DigiData 1440A Data Acquisition System (Molecular Devices), and recorded digitally using pClamp 10.2 (Molecular Devices). EEG traces are 
representative data from one animal undergoing each drug treatment so that traces can be directly compared between treatments. The frequency of synchronous spikes in EEG activity were analyzed using pClamp 10.2. Positive-going activity that exceeded three times the SD of the amplitude under basal conditions were marked as synchronous spikes in activity.

A $\beta$ ELISAs. ISF A $\beta$ levels were assessed using sandwich ELISAs as described previously (Kim et al., 2009). Briefly, a mouse anti-A $\beta_{40}$ antibody (mHJ2) or mouse anti-A $\beta_{42}$ antibody (mHJ7.4) was used to capture and a biotinylated central domain antibody (mHJ5.1) was used to detect, followed by streptavidin-poly-HRP-40 (Fitzgerald Industries). All ELISA assays were developed using Super Slow ELISA TMB (Sigma) and absorbance read on a BioTek Epoch plate reader at $650 \mathrm{~nm}$. These assays equally recognize human and murine $\mathrm{A} \beta$ so the same assays were used for samples generated in PS1APP human APP transgenic mice and wild-type mice. The standard curves for each assay, however, used either human or mouse $\mathrm{A} \beta$ peptide.

Western blots. Three-month-old PS1APP mice treated with vehicle or CPP by intraperitoneal injection and $8 \mathrm{~h}$ later were killed by cardiac perfusion with chilled saline with $0.3 \%$ heparin and the hippocampus microdissected and snap frozen on dry ice. Hippocampal tissue was homogenized by sonication in 10:1 volume:wet weight of $150 \mathrm{~mm} \mathrm{NaCl}, 50$ mm Tris, pH 7.4, 0.5\% deoxycholic acid, 0.1\% SDS, 1\% Triton X-100, 2.5 mM EDTA, and protease inhibitors. Western blotting for full-length APP was performed using 4-12\% Bis-Tris NuPAGE gels (Invitrogen) under reducing conditions with $15 \mu \mathrm{g}$ of protein loaded per lane. Nitrocellulose blots were probed with rabbit anti-APP directed against the $\mathrm{C}$ terminus of APP (Invitrogen), followed by donkey anti-rabbit antibody reabsorbed against mouse IgG and conjugated to peroxidase (Santa Cruz Biotechnology). Gels were stripped and reprobed with rabbit antitubulin (Sigma) as a loading control protein. Bands were detected with Lumigen-TMA6 (GE Healthcare) and captured digitally using the Kodak ImageStation 440CF. Densitometry was performed using the Kodak 1D Image Analysis software and each band normalized to tubulin signal in each lane.

ERK pathway multiplex assay. Hippocampal tissue was isolated from CPP (20 mg/kg, i.p.) and vehicle-treated PS1APP mice ( $8 \mathrm{~h}$ treatment) were then lysed in the EpiTag Cell Lysis Kit (Novagen) by mechanical homogenization. ERK2 total protein and phosphorylated forms of MEK1/2 and ERK2 were measured together using the WideScreen EpiTag ERK Pathway Panel I (Novagen) with concentrations calibrated against the EpiTag ERK Pathway Standards Mix. Bead fluorescence was quantified using the xMAP Luminex platform.

Secretase assays. Enzymatic activity of $\alpha$-secretase and $\beta$-secretase was measured using FRET-based cleavage assays (R\&D Systems). Hippocampal tissue was isolated from CPP (20 mg/kg, i.p.) and vehicle-treated PS1APP mice ( $8 \mathrm{~h}$ treatment) were then lysed in Cell Extraction Buffer (Novagen) by mechanical homogenization. Cell extracts were incubated with secretase-specific peptides conjugated to the reporter molecules EDANS and DABCYL for 15-30 min. EDANS fluorescence was read on a Synergy 2 microtiter plate reader (BioTek).

Statistics. Data in figures are presented as mean \pm SEM. All statistical analysis was performed using Prism version 5.04 for Windows (GraphPad). Statistical analysis to compare the mean values for multiple groups was performed using a one-way ANOVA with correction for multiple comparisons. Comparison of only two groups was performed using a two-tailed unpaired $t$ test. Analysis of effects of drug versus vehicle treatment over time was done with a repeatedmeasures two-way ANOVA with correction for multiple comparisons. Values were accepted as significant if $p \leq 0.05$.

\section{Results \\ Differential dose-dependent effect of NMDA-R signaling on ISF A $\beta$ levels in vivo}

$\mathrm{A} \beta$ is produced primarily within neurons and secreted into the brain extracellular fluid, or ISF. We used a brain microdialysis technique to specifically measure dynamic changes in ISF A $\beta$ levels over time in living mice (Cirrito et al., 2003, 2008). This technique permits serial sampling of ISF $A \beta$ up to every hour for several days while the mice are awake and have freedom of movement. Agents can be administered to these mice either by intraperitoneal injection or can be administered directly to the brain by adding the compound to the microdialysis probe perfusion buffer, a technique called reverse microdialysis. Compounds within the perfusion buffer diffuse out of the probe and into the brain, simultaneous with $\mathrm{A} \beta$ diffusion into the probe, allowing for a continuous application of drug with minimal tissue disruption and while bypassing the blood-brain barrier.

Three- to four-month-old PS1APP hemizygous transgenic mice were implanted with hippocampal microdialysis probes (Cirrito et al., 2003). Mice at this age do not yet contain $\mathrm{A} \beta$ deposits, thus allowing us to study normal brain $\mathrm{A} \beta$ metabolism without complicating factors, such as $\mathrm{A} \beta$ aggregates, which could alter the equilibrium and metabolism of extracellular $A \beta$. The basal ISF A $\beta$ concentration for each mouse was established over a $6 \mathrm{~h}$ period followed by treatment with a dose escalation of NMDA by reverse microdialysis. The concentration of NMDA within the microdialysis probe was gradually stepped from 0.25 to $250 \mu \mathrm{M}$ with exposure to each dose lasting $3 \mathrm{~h}$. Administration of 0.25 to $1 \mu \mathrm{M}$ NMDA significantly elevated ISF $\mathrm{A} \beta_{40}$ levels by $30-75 \%$ over basal levels with the peak increase at $0.5 \mu \mathrm{M}$ NMDA (Fig. $1 A$ ). Doses between 2 and $10 \mu \mathrm{M}$ NMDA had no effect on ISF $\mathrm{A} \beta_{40}$ levels, whereas doses of $20 \mu \mathrm{M}$ and above caused a significant depression in ISF A $\beta$ levels. For instance, $40 \mu \mathrm{M}$ NMDA caused an $\sim 50 \%$ decrease in ISF A $\beta$. Levels of $\mathrm{A} \beta_{42}$ were affected in a similar way as $\mathrm{A} \beta_{40}$ by both the low and high doses of NMDA (Fig. 1B).

To confirm that NMDA-Rs underlie the dose-dependent regulation of $\mathrm{A} \beta$ metabolism (Fig. $1 A$ ), we performed a similar dose-response study using homoquinolinic acid (HQ), another selective agonist for NMDA-Rs (Grimwood et al., 2002). Similar to NMDA, low doses of HQ $(0.25-1 \mu \mathrm{M})$ increased ISF A $\beta$ levels, whereas high doses of HQ (5-20 $\mu \mathrm{M})$ depressed $\mathrm{A} \beta$ levels significantly. The peak increase in ISF $A \beta$ occurred at $0.25 \mu \mathrm{M}$ HQ (increased by $50.0 \pm 2.7 \%$ of basal levels). Infusion of $20 \mu \mathrm{M}$ HQ reduced ISF A $\beta$ by $54.5 \pm 2.3 \%$ of basal levels ( $n=5$ per group).

Interestingly, other types of glutamate receptors can also modulate ISF A $\beta$ levels. Metabotropic glutamate receptor $2 / 3$ agonists suppress ISF $A \beta$ levels (Cirrito et al., 2005), whereas antagonists increase $\mathrm{A} \beta$ (Cirrito et al., 2008). Baseline AMPA receptor (AMPA-R) activity increases ISF A $\beta$ levels in vivo. Infusion of an AMPA-R antagonist, NBQX ( $10 \mu \mathrm{M}$ by reverse microdialysis), into the hippocampus suppressed ISF $A \beta$ levels by $21.7 \pm 1.5 \%$ compared to vehicle-treated mice $(p=0.0002)$. These receptors are responsible for much of the excitatory neurotransmission within the brain, so blocking AMPA-Rs reduces synaptic activity, which likely reduces synaptic $A \beta$ generation (Cirrito et al., 2005). Whether similar or distinct mechanisms are used by NMDA-Rs and other types of glutamate receptors to modulate ISF $A \beta$ levels are unknown.

Our original hypothesis was that this excitatory neurotransmitter would depolarize neurons, increase synaptic activity, and consequently elevate brain ISF A $\beta$ levels. In our studies, low doses of NMDA resulted in effects consistent with this hypothesis; low doses of NMDA infused directly into the brain elevated synaptic transmission and $\mathrm{A} \beta$ generation within hours. Surprisingly, however, as we gradually increased the dose of NMDA, there was a dose-dependent decrease in ISF A $\beta$ levels that was contrary to the initial hypothesis. 

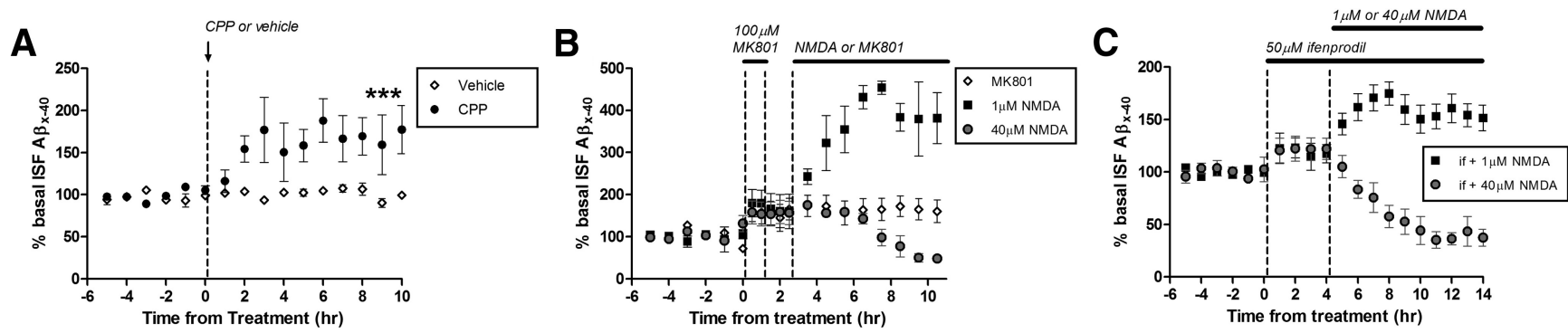

Figure 2. NMDA-R antagonists increase ISF $A \beta$ levels. $A$, NMDA-R antagonist CPP ( $20 \mathrm{mg} / \mathrm{kg}$ i.p.) increased ISF A $\beta$ levels by $77.4 \pm 28.7 \%$ compared to vehicle-treated (saline) PS1APP mice at $10 \mathrm{~h}$ after treatment ( $p<0.05, n=6$ per group). $\boldsymbol{B}$, MK801 (100 $\mu \mathrm{m}$ by reverse microdialysis), a use-dependent NMDA-R antagonist, was infused into the hippocampus for 60 min followed by a 90 min washout and reapplication of MK801, $1 \mu \mathrm{M} \mathrm{NMDA}$, or $40 \mu \mathrm{M} \mathrm{NMDA} \mathrm{for} 8 \mathrm{~h}\left(n=5\right.$ per group). MK801 alone significantly increased ISF $A \beta_{40}$ by $60.7 \pm 16.6 \%$ ( $\left.p<0.05\right)$ compared to basal levels. One micromolar NMDA increased ISF A $\beta$ by $281.7 \pm 60 \%(p<0.01)$, whereas $40 \mu$ M NMDA reduced A $\beta$ by $49.6 \pm 7.1 \%(p<0.05)$ compared to basal levels. $C$, Infusion of the NR2B subunit-selective antagonist, ifenprodil $(50 \mu \mathrm{M})$, alone increased ISF A $\beta_{40}$ by $19.3 \pm 3.3 \%(p<0.05)$ compared to basal levels. Cotreatment of ifenprodil and either $1 \mu \mathrm{M}$ NMDA or $40 \mu \mathrm{M}$ NMDA increased $A \beta$ by $51.6 \pm 12.2 \%(p<0.05)$ and decreased $A \beta$ by $62.5 \pm 7.9 \%(p<0.0001 ; n=5-6$ per group $)$, respectively. Data are presented as mean \pm SEM. ${ }^{* * *} p<0.001$.

$\mathrm{A} \boldsymbol{\beta}$ is reduced despite dramatic elevations in neuronal activity Neurotransmitter receptors can have paradoxical effects on neural networks, especially in the case of receptors that desensitize following intense activation or in the case of excitatory receptors on inhibitory interneurons. To determine how various doses of NMDA affected neuronal activity, we assessed extracellular field potentials, or depth EEG, within the hippocampus of mice being administered NMDA via reverse microdialysis (Fig. 1C). The EEG recording electrodes were attached directly to the microdialysis guide cannula to record electrical activity at the same location that NMDA was administered and $\mathrm{A} \beta$ was collected (Cirrito et al., 2005). Under basal conditions, there were synchronous spikes in EEG activity at a frequency of $0.03 \pm 0.007 \mathrm{~Hz}$ (mean \pm SEM; $n=5$ ). One micromolar NMDA had a small, but significant, effect on recorded EEG; new synchronous spikes in activity occurred with a frequency of $0.1 \pm 0.013 \mathrm{~Hz}(p<0.05)$. Increasing the dose to $40 \mu \mathrm{M}$ NMDA had a more dramatic effect on EEG activity with spikes in activity occurring at $0.23 \pm 0.03 \mathrm{~Hz}(p<$ 0.01 ). This elevated activity, however, was subthreshold for epileptiform activity. At doses of $250 \mu \mathrm{M}$ NMDA, EEG activity was dramatically higher with spikes in activity occurring at $1.7 \pm 0.13$ $\mathrm{Hz}(p<0.0001)$ and epileptiform activity occurring several times during a $3 \mathrm{~h}$ administration though this activity did not generalize to result in a behavioral manifestation. Very low doses of NMDA elevated ISF $A \beta$ levels, which is consistent with our previous publications of a presynaptic generation of $\mathrm{A} \beta$ that is tightly coupled to synaptic transmission (Cirrito et al., 2005, 2008). The reduction in $\mathrm{A} \beta$ by higher doses of NMDA, however, did not appear to be due to this synaptic generation of $A \beta$ given that even in the presence of hippocampal seizures, ISF A $\beta$ levels were still dramatically reduced.

The $\mathrm{EC}_{50}$ of NMDA at NMDA-Rs is $35 \mu \mathrm{M}$ in vitro (Patneau and Mayer, 1990). Delivered by reverse microdialysis in vivo, NMDA concentrations of $0.25-1 \mu \mathrm{M}$ (or lower within the parenchyma) should activate only a very small percentage of receptors [estimated $1 \%$ bound at $1 \mu \mathrm{M}$ NMDA based on Patneau and Mayer (1990)]. Given that almost all neurons within the brain express NMDA-Rs, this small percentage is likely a large number of receptors that are activated. In support of this, $1 \mu \mathrm{M}$ NMDA delivered by reverse microdialysis increases neuronal activity as detected by increased synchronous spikes in EEG recordings (Fig. 1C).

\section{Reductions in ISF A $\beta$ are not due to neuronal injury}

Glutamate receptor overstimulation is known to cause excitotoxic injury to neurons (Olney and Sharpe, 1969). We postulated that the decrease in ISF A $\beta$ could be due to cell death as opposed to a true change in $\mathrm{A} \beta$ metabolism. We infused $40 \mu \mathrm{M}$ NMDA into the hippocampus for $6 \mathrm{~h}$, which caused a rapid decrease in ISF $\mathrm{A} \beta$ (Fig. $1 D$ ). At the end of $6 \mathrm{~h}$ of treatment, NMDA was removed from the microdialysis perfusion buffer and ISF A $\beta$ levels were measured for an additional $36 \mathrm{~h}$. During this washout period, ISF A $\beta$ levels gradually returned to baseline levels ( $96 \%$ of baseline at $30 \mathrm{~h}$ from the beginning of the washout period). The complete recovery of $A \beta$ levels strongly suggests that the depression in $\mathrm{A} \beta$ by $40 \mu \mathrm{M}$ NMDA was not caused by an excitotoxic lesion. In addition, FluoroJade $\mathrm{B}$ staining around the microdialysis probe, to detect degenerating cells, did not show increased reactivity in mice administered $40 \mu \mathrm{M}$ NMDA (data not shown). Studies described later will demonstrate that the depression in $\mathrm{A} \beta$ by $40 \mu \mathrm{M}$ NMDA can be blocked with several agents, further suggesting the depression in $A \beta$ is caused by altered cellular metabolism as opposed to neuronal injury. This is also consistent with other publications that have delivered similar concentrations of NMDA to the brain via reverse microdialysis and detected physiological alterations as a consequence (Duva et al., 2001).

\section{NMDA-R antagonists increase ISF A $\beta$ levels}

To determine how endogenous NMDA-R signaling alters $A \beta$ levels, we administered CPP, a selective NMDA-R antagonist, systemically to PS1APP transgenic mice. CPP (20 mg/kg i.p.) caused a significant $75 \%$ increase in ISF $A \beta$ levels over $3 \mathrm{~h}$, which remained high until at least $10 \mathrm{~h}$ after treatment compared to vehicle-treated mice (Fig. $2 A$ ). This demonstrates that basal NMDA-R signaling within the hippocampus normally suppresses A $\beta$ levels. Since CPP does not cause excitotoxicity, this is also further evidence that modulation of $A \beta$ levels is a physiological response to NMDA-R signaling and not due to degenerating neurons.

Paradoxically, low doses of exogenous NMDA have the opposite effect on $A \beta$ than endogenous NMDA signaling has, suggesting that a separate population of receptors underlie the two phenomenon. To remove the basally active NMDA-Rs for the experimental system, we infused MK801, a noncompetitive usedependent NMDA-R antagonist, into the hippocampus. This compound will only block NMDA-Rs that have open channels when the drug is present (Huettner and Bean, 1988; Ivanov et al., 2006). Similar to CPP, MK801 increased ISF $A \beta$ levels by $60 \%$ (Fig. $2 B$ ). After 60 min of administration, MK801 was removed from the microdialysis perfusion buffer to wash out existing compound from the brain for $90 \mathrm{~min}$. One cohort of PS1APP 


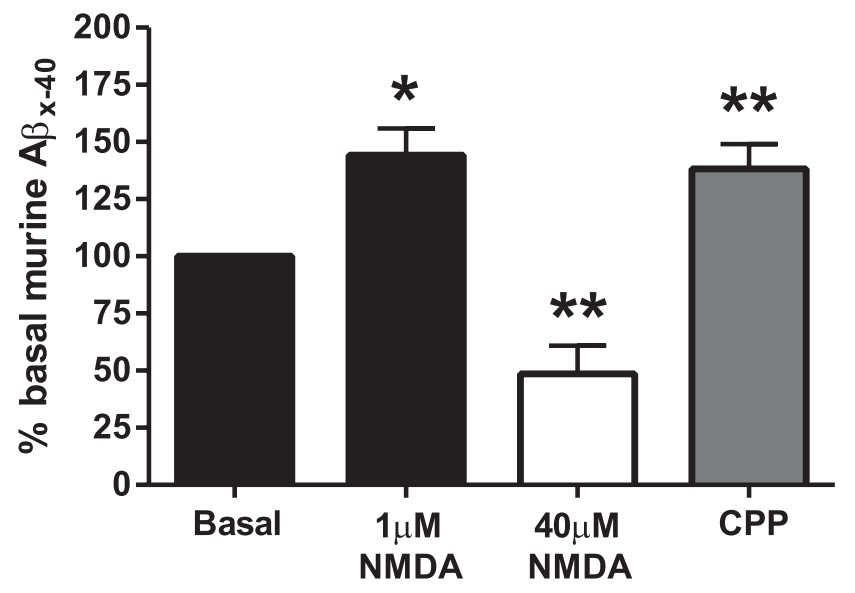

Figure 3. Effect of NMDA-R modulation on endogenous murine $A \beta$ levels. ISF $A \beta$ levels in wild-type C57BL6 mice increased by $44.2 \pm 11.7 \%\left({ }^{*} p<0.05\right)$ and decreased by $51.4 \pm$ $12.3 \%(p<0.01)$ compared to basal levels in response to 1 and $40 \mu \mathrm{m}$ NMDA delivered into the hippocampus by reverse microdialysis ( $n=5-6$ per group). CPP ( $20 \mathrm{mg} / \mathrm{kg}$, i.p.) elevated A $\beta$ levels by $38.3 \pm 10.7 \%\left({ }^{* *} p<0.01\right)$ compared to basal levels in each mouse $(n=5)$. Data presented as mean \pm SEM.

mice had MK801 reapplied after the washout period. In these mice, ISF A $\beta$ levels did not have an additional change, suggesting that during the washout phase no new NMDA-Rs were recruited to regulate $\mathrm{A} \beta$ metabolism. A second and third cohort of mice were administered either 1 or $40 \mu \mathrm{M}$ NMDA after the washout period, which caused an increase in $\mathrm{A} \beta$ by $280 \%$ and a decrease by $50 \%$, respectively (Fig. $2 B$ ). This suggests that exogenous application of NMDA activates a separate set of receptors, likely on separate neurons, from those used under basal conditions to regulate $\mathrm{A} \beta$ metabolism.

A functional NMDA-R consists of two NR1 subunits (out of eight known subunits) and two NR2 subunits (out of four known subunits). The combination of subunits within each receptor impacts the receptor's properties, such as kinetics and localization. For instance, NR2B-containing receptors can be localized axonally and at extrasynaptic sites (Köhr, 2006). To determine whether NR2B receptors modulate $\mathrm{A} \beta$ metabolism, we infused ifenprodil, a NR2B-selective inhibitor, into the hippocampus. Ifenprodil alone increased ISF A $\beta$ levels by $20 \%$ (Fig. $2 C$ ). Pretreatment with ifenprodil marginally affected the change in $\mathrm{A} \beta$ metabolism by either low- or high-dose NMDA (Fig. 2C). This suggests that NR2B-containing receptors likely account for a relatively small portion of synaptic-dependent $A \beta$ metabolism.

NMDA-R modulation alters endogenous murine $\mathrm{A} \beta$ levels As with any transgenic animal model, a concern is that an observation could be due to overexpression of a protein as opposed to a normal cellular process. Using microdialysis, we established basal ISF murine $A \beta$ levels in the hippocampus of young wildtype C57BL6 mice and then administered either $1 \mu \mathrm{M}$ NMDA or $40 \mu \mathrm{M}$ NMDA for $4 \mathrm{~h}$ by reverse microdialysis. A low dose of NMDA caused a significant $45 \%$ increase in ISF A $\beta$, whereas a high dose caused a $50 \%$ reduction in $\mathrm{A} \beta$ (Fig. 3 ). Similarly, CPP caused a $50 \%$ increase in ISF murine $A \beta$ levels in C57BL6 mice (Fig. 3). These data demonstrate that NMDA-Rs modulate physiological A $\beta$ metabolism.

Action potentials are only required for NMDA-dependent elevations in ISF A $\beta$

To determine whether NMDA-dependent changes to $\mathrm{A} \beta$ were primarily due to depolarization/action potentials or to signaling cascades activated by these receptors, we pretreated mice with TTX for $15 \mathrm{~h}$ and then coinfused TTX with either $1 \mu \mathrm{M}$ NMDA or $40 \mu \mathrm{M}$ NMDA into the hippocampus for $8 \mathrm{~h}$ (Fig. $4 A$ ). In the presence of TTX, infusion of NMDA will activate NMDA-Rs normally; however, the neuronal response is limited to local action of NMDA-Rs. TTX alone reduced A $\beta$ levels by $40 \%$ similar to previous reports (Kamenetz et al., 2003; Cirrito et al., 2005). TTX completely blocked the increase in ISF A $\beta$ levels caused by 1 $\mu \mathrm{M}$ NMDA (Fig. $4 \mathrm{~B}$ ); however, $40 \mu \mathrm{M}$ NMDA still caused a significant $45 \%$ reduction in ISF A $\beta$ levels compared to TTX treatment alone. As expected, even though NMDA-Rs were activated, TTX blocked the downstream neuronal activity caused by both concentrations of NMDA as measured by hippocampal EEG (Fig. $4 C$ ). This suggests that low doses of NMDA require action potentials to increase $\mathrm{A} \beta$ generation (Cirrito et al., 2005, 2008), but in contrast, reduction of $\mathrm{A} \beta$ by high doses of NMDA do not.

\section{Calcium is necessary for NMDA-dependent changes of ISF A $\beta$}

NMDA-Rs are cation channels that are primarily permeable to sodium and calcium influx. Given that calcium can have a multitude of effects within a cell, we determined whether calcium entry was responsible for the NMDA-dependent changes in ISF $\mathrm{A} \beta$. Basal ISF $\mathrm{A} \beta$ levels were determined in PS1APP mice followed by administration of vehicle or BAPTA-AM, a calcium chelator, by reverse microdialysis for $6 \mathrm{~h}$ (Fig. 5A). BAPTA-AM alone increased ISF A $\beta$ levels by $27 \%$ by the end of treatment, suggesting that some basal calcium signaling normally lowers ISF $\mathrm{A} \beta$. Beginning at hour 7, BAPTA-AM was coadministered with either $1 \mu \mathrm{M}$ NMDA or $40 \mu \mathrm{M}$ NMDA for an additional $8 \mathrm{~h}$. One micromolar NMDA only increased ISF A $\beta$ levels by $10 \%$ in the presence of BAPTA-AM when normalized to BAPTA-AM treatment alone (Fig. $5 B$ ). This increase could be driven by residual presynaptic cycling supported by any unchelated calcium that remains. BAPTA-AM also reduced the effect of $40 \mu \mathrm{M}$ NMDA. Forty micromolar NMDA only reduced ISF A $\beta$ by $30 \%$ in the presence of the calcium chelator when normalized to pretreatment levels. Not surprisingly, these data suggest that calcium is at least partially responsible for both the elevation and depression of ISF A $\beta$ by NMDA. In vivo, it is unlikely that all free calcium is buffered by BAPTA-AM; therefore, it is still possible that NMDA entirely requires calcium to modulate $\mathrm{A} \beta$ levels.

\section{ERK signaling is required for NMDA-dependent depression of ISF A $\beta$ levels}

Calcium influx through NMDA-Rs can lead to activation of several second messenger signaling pathways, including the extracellular regulated kinase (ERK) pathway (Bading and Greenberg, 1991; Kurino et al., 1995; Xia et al., 1996; Ivanov et al., 2006). ERK is a mitogen-activated protein kinase (MAPK) that is activated by a wide variety of extracellular ligands (Boulton and Cobb, 1991). In this signaling cascade, an extracellular ligand leads to activation of Raf kinase, which results in sequential phosphorylation of MEK and then ERK, which is the active form of this kinase. Phosphorylated ERK (pERK) acts within the cytoplasm to phosphorylate other proteins and alter their function or it translocates to the nucleus to alter gene transcription.

In PS1APP hemizygous mice, we blocked the ERK signaling pathway by infusing agents that inhibit either MEK (PD98059) or ERK (FR180204) through the microdialysis probe. These inhibitors alone increased ISF A $\beta$ levels by $58 \%$ and $42 \%$, respectively (Fig. 5C). Interestingly, however, in the presence of either inhibitor, $40 \mu \mathrm{M}$ NMDA no longer decreased ISF A $\beta$ levels but instead 


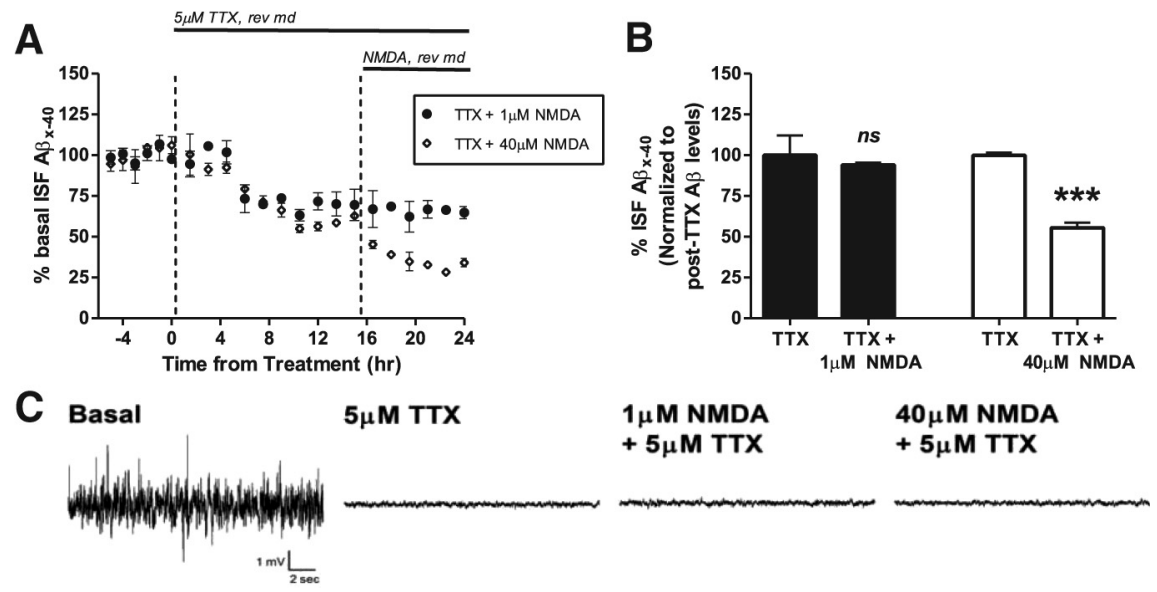

Figure 4. Presynaptic versus postsynaptic mechanisms that regulate $A \beta$ metabolism. $A, \operatorname{TTX}(5 \mu \mathrm{M})$ was delivered continuously into the hippocampus by reverse microdialysis for $16 \mathrm{~h}$ followed by coinfusion with either 1 or $40 \mu \mathrm{M} \mathrm{NMDA}$. $\boldsymbol{B}$, In this setting, $1 \mu \mathrm{M}$ NMDA had no effect on ISF $A \beta$ levels, whereas $40 \mu \mathrm{M}$ NMDA reduced ISF $A \beta$ levels by $44.4 \pm 3.1 \%$ compared to levels during hour 16 of TTX-treatment alone ( $\left.{ }^{* * *} p<0.001\right)$. ( $n=5-6$ per group). C, Representative EEG traces during a dose escalation of NMDA during TTX treatment. TTX ( $5 \mu \mathrm{m}$ ) was delivered for $16 \mathrm{~h}$, followed by $3 \mathrm{~h}$ each of $1 \mu \mathrm{m}$ and then $40 \mu \mathrm{M}$ NMDA ( $n=3$ mice). Data presented as mean \pm SEM.

dramatically increased ISF $A \beta$ levels by twofold and threefold compared to basal levels in each mouse (Fig. 5D). Inhibitors of two different points of the ERK signaling cascade block the effect of $40 \mu \mathrm{M}$ NMDA, strongly suggesting that the ERK signaling cascade is required for the NMDA-dependent reduction in ISF A $\beta$. In contrast, an inhibitor of calcium/calmodulin kinase (CaMK), KN93, did not block the reduction in ISF $\mathrm{A} \beta$ by $40 \mu \mathrm{M}$ NMDA. Neither the MEK nor ERK inhibitor affected the increase in ISF A $\beta$ levels by $1 \mu \mathrm{M}$ NMDA (data not shown), demonstrating that ERK signaling is only required for depression of ISF $\mathrm{A} \beta$ but not action potential-mediated synaptic $\mathrm{A} \beta$ generation.

The remarkable elevation in $A \beta$ by coadministration of ERK pathway inhibitors and $40 \mu \mathrm{M}$ NMDA was likely due to synaptic mechanisms that generate $A \beta$ as a consequence of synaptic transmission (Cirrito et al., 2005). To test this hypothesis directly, we pretreated PS1APP mice with TTX and then FR180204 to block action potentials and ERK signaling, then cotreated with $40 \mu \mathrm{M}$ NMDA. In this setting, ISF A $\beta$ levels did not change compared to pretreatment levels (Fig. 5E), suggesting that blocking the ERK signaling that reduces APP processing into $\mathrm{A} \beta$ as well as blocking synaptic $A \beta$ generation is sufficient to prevent NMDA from altering ISF $A \beta$ levels at all.

\section{Only select ERK activators regulate $A \boldsymbol{\beta}$ metabolism}

Numerous receptors and signaling pathways can converge to activate ERK, which in turn can have a multitude of downstream transcriptional or protein targets. ERK activation and activity, however, is highly regulated and can have very precise biological responses in large part due to cellular context, scaffold proteins, and compartmentalization where it is activated (for review, see Pouysségur et al., 2002). We determined the extent that other ERK activators would impact $\mathrm{A} \beta$ metabolism. Using reverse microdialysis, we infused a Trk-B receptor agonist [7,8-dihydroxyflavone (DHF)], a glucocorticoid receptor ligand (allopregnanolone), or a serotonin receptor ligand (serotonin) into the brain (Fig. $5 F$ ). In addition to the many effects these pathways have within a neuron, ERK is also activated (Hetman et al., 1999; Basta-Kaim et al., 2007; Cowen, 2007). Interestingly, neither activation of Trk-B receptors nor glucocorticoid receptors altered ISF A $\beta$ levels. Infusion of serotonin however significantly reduced ISF A $\beta$ levels by $20 \%$ (Fig.
$5 F)$. The particular cellular cues, cofactors, and scaffold proteins that underlie this downstream substrate specificity are still unknown.

\section{NMDA-R signaling alters secretase cleavage of APP}

We sought to determine the mechanisms by which NMDA-R signaling alters $A \beta$ levels. To alter NMDA-R signaling uniformly throughout the brain, PS1APP were administered vehicle or the NMDA-R antagonist CPP by intraperitoneal injection. Eight hours after treatment, tissue was harvested and processed for a Luminex bead-based assay to measure various components of the ERK cascade. CPP did not alter total ERK2 (Fig. $6 A$ ) or ERK1 (data not shown) protein levels; however, the phosphorylated active forms of both the ERK2 and MEK1/2 were significantly reduced (Fig. 6A). PhosphoERK1 protein levels were not detectable with this assay. Full-length APP levels were unaffected by CPP administration (Fig. 6B); however, APP C-terminal fragment (CTF)- $\alpha$ was significantly reduced by $15.2 \pm 2.1 \%$ compared to vehicle-treated mice ( $p<0.05 ; n=8$ per group), while APP CTF- $\beta$ was unaffected.

ERK signaling has been shown to increase $\alpha$-secretase activity (Kojro et al., 2006) and decrease $\gamma$-secretase activity (Kim et al., 2006; Tung et al., 2008), both of which are consistent with the depression in ISF A $\beta$ caused by $40 \mu \mathrm{M}$ NMDA. We measured enzymatic activity of $\alpha$-secretase and $\beta$-secretase in brain homogenates from the CPP and vehicle-treated PS1APP mice using fluorometric cleavage assays. Eight hours after CPP treatment, $\alpha$-secretase activity was significantly reduced, whereas $\beta$-secretase activity was unaltered within the hippocampus (Fig. 6C); enzymatic activity was consistent with our observed changes in APP-CTFs. Whether ERK causes a posttranslational or transcriptional effect to alter $\alpha$-secretase activity in vivo is still unclear. Interestingly, presenilin-1 (PS1) protein levels were elevated as assessed by Western blot (Fig. 6B). Both of these changes in APP processing are consistent with an elevation in ISF $A \beta$ levels following NMDA-R antagonist treatment.

\section{Discussion}

The relationship between synaptic activity and regulation of $A \beta$ levels is complex. A single neurotransmitter receptor, such as NMDA-R, can simultaneously activate multiple mechanisms within a cell to differentially regulate $A \beta$ generation. Calcium influx through these receptors depolarizes and excites neurons leading to synaptic transmission, which is closely linked to synaptic $\mathrm{A} \beta$ generation. Calcium also acts as a second messenger. When sufficient calcium levels are reached through high levels of NMDA-R activity, the ERK signaling cascade is activated, which depresses APP processing into $\mathrm{A} \beta$, likely via enhancing $\alpha$-secretase cleavage activity. Our studies administering NMDA to the hippocampus demonstrate that this neurotransmitter system can have dramatic effects on $A \beta$ levels with up to a $75 \%$ reduction at the highest doses of NMDA. Given that NMDA-R antagonists, in both APP transgenic and wild-type mice, elevate $A \beta$ levels, it appears that basal signaling through these receptors contributes to normal suppression of $A \beta$ generation. 
Model of NMDA-dependent mechanisms that regulate

\section{$\mathrm{A} \boldsymbol{\beta}$ generation}

Low doses of exogenous NMDA depolarize neurons, elevate synaptic transmission, and increase $\mathrm{A} \beta$ generation and secretion (Fig. 7A). Recruitment of NMDA-Rs and neurons that are not active under basal conditions appear to be responsible for this increase in $\mathrm{A} \beta$. While this can occur via a presynaptic mechanism that requires clathrin-mediated endocytosis (Cirrito et al., 2008), other areas of a neuron may also contribute to this increase in generation. In contrast, high doses of NMDA activate the ERK signaling pathway, which downregulates APP processing into $A \beta$ despite increased synaptic activity (Fig. 7B). This depression in $\mathrm{A} \beta$ appears to be in part due to enhanced $\alpha$-secretase enzymatic activity. We propose that at low levels of NMDA-R activation, very little ERK is activated; thus, the balance is shifted so that synaptic transmission drives $\mathrm{A} \beta$ generation. Strong NMDA-R activation, however, recruits ERK, which reduces APP processing into $\mathrm{A} \beta$. The balance between enhancing $\mathrm{A} \beta$ generation and depressing APP processing determines the total amount of $\mathrm{A} \beta$ that a neuron will produce at a given time. Midrange doses of NMDA (Fig. 1A) $(2-10 \mu \mathrm{M})$ had no net change in ISF $\mathrm{A} \beta$ levels; this likely represents an equal balance of these competing pathways. Under normal conditions, basal NMDA-R signaling is sufficient to drive ERK activation and suppress AP processing into $\mathrm{A} \beta$. This likely occurs in a subpopulation of neurons where either baseline NMDA-R activity is high or at a set of NMDA-Rs that are particularly capable to activating ERK.

Neuronal depolarization and synaptic transmission lead to APP endocytosis and $\mathrm{A} \beta$ generation and then secretion (Cirrito et al., 2008). This appears to be a normal metabolic pathway for $A \beta$ generation. Increasing synaptic activity in a cell may simply drive more APP through this pathway and therefore generate more $A \beta$. In contrast, changing APP processing via secretase activity alters the ability of a cell to produce A $\beta$. APP is primarily cleaved by $\alpha$-secretase within the secretory pathway (Lammich et al., 1999), which is upstream of endocytic events that lead to $\mathrm{A} \beta$ generation (Koo and Squazzo, 1994). Thus, in the presence of $40 \mu \mathrm{M}$ NMDA, elevated $\alpha$-secretase activity cleaves APP, which reduces the substrate available for later $\mathrm{A} \beta$ generation within endosomes (Fig. $1 A$ ). When ERK signaling is inhibited, however, $40 \mu \mathrm{M} \mathrm{NMDA}$ has no effect on the APP substrate; thus, a dramatic increase in synaptic $A \beta$ generation is unmasked (Fig. $5 C$ ).

\section{Basal NMDA-R and ERK activity lowers ISF A $\beta$ levels}

Administration of NMDA-R antagonists or inhibitors of the ERK signaling cascade block steady-state activity and increase ISF A $\beta$ levels. This suggests that there is a physiologic suppression of $A \beta$ levels by NMDA-Rs and by ERK in vivo. NR2B-containing receptors appear to account for only a small portion of the basal suppression in $\mathrm{A} \beta$ since ifenprodil (NR2B-selective) only increases $\mathrm{A} \beta$ by $20 \%$, whereas broader antagonists such as MK801 and CPP and increase $\mathrm{A} \beta$ by $60-75 \%$.

\section{NMDA receptors, ERK, and A $\beta$ metabolism}

Two very similar studies have assessed the role of NMDA-Rs in $\mathrm{A} \beta$ metabolism in neuronal culture and produced conflicting evidence. Lesné et al. (2005) determined that NMDA increased $\mathrm{A} \beta$ production and $\mathrm{A} \beta$ levels in primary neuronal cultures by reducing $\alpha$-secretase activity. In contrast, Hoey et al. (2009) found that NMDA reduced $\mathrm{A} \beta$ generation in culture. This reduction in $\mathrm{A} \beta$ was associated with activated ERK and nonamyloidogenic processing of APP. Ironically, our in vivo data are consistent with both of these studies. We propose that the difference between these studies may be the degree of ERK activation or another component of that signaling cascade. NMDA-R expression or activity could shift the balance between the $A \beta$ generation and 

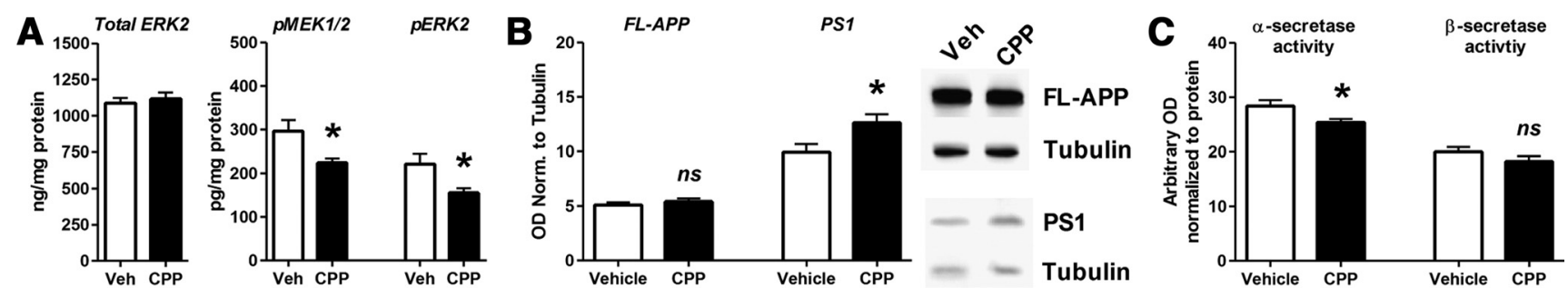

Figure 6. ERK signaling alters processing of APP. CPP ( $20 \mathrm{mg} / \mathrm{kg}$, i.p.) or vehicle (saline) was delivered to PS1APP ${ }^{+/-}$mice and brains removed $8 \mathrm{~h} \mathrm{later} \mathrm{for} \mathrm{biochemical} \mathrm{analysis}(n=8 \mathrm{mice}$ per group). $\boldsymbol{A}$, ERK2 total protein levels did not change following (PP treatment; however, phospho-MEK1/2 and phospho-ERK2 protein levels were reduced by $24.2 \pm 9.6 \%$ and $29.0 \pm 10.7 \%$, respectively $(p<0.05)$. $\boldsymbol{B}$, Full-length APP protein levels, as assessed by SDS-PAGE/Western blot, were not altered by CPP treatment. However, total presenilin-1 protein levels were significantly increased by $26.7 \pm 1.9 \%(p<0.05)$. $\boldsymbol{C}$, $\alpha$-Secretase enzymatic activity was decreased by $8.9 \pm 1.3 \%$ compared to vehicle-treated mice $(p<0.05)$, whereas $\beta$-secretase activity was unaltered. $D$, Data are presented as mean \pm SEM. ${ }^{*} p<0.05$.
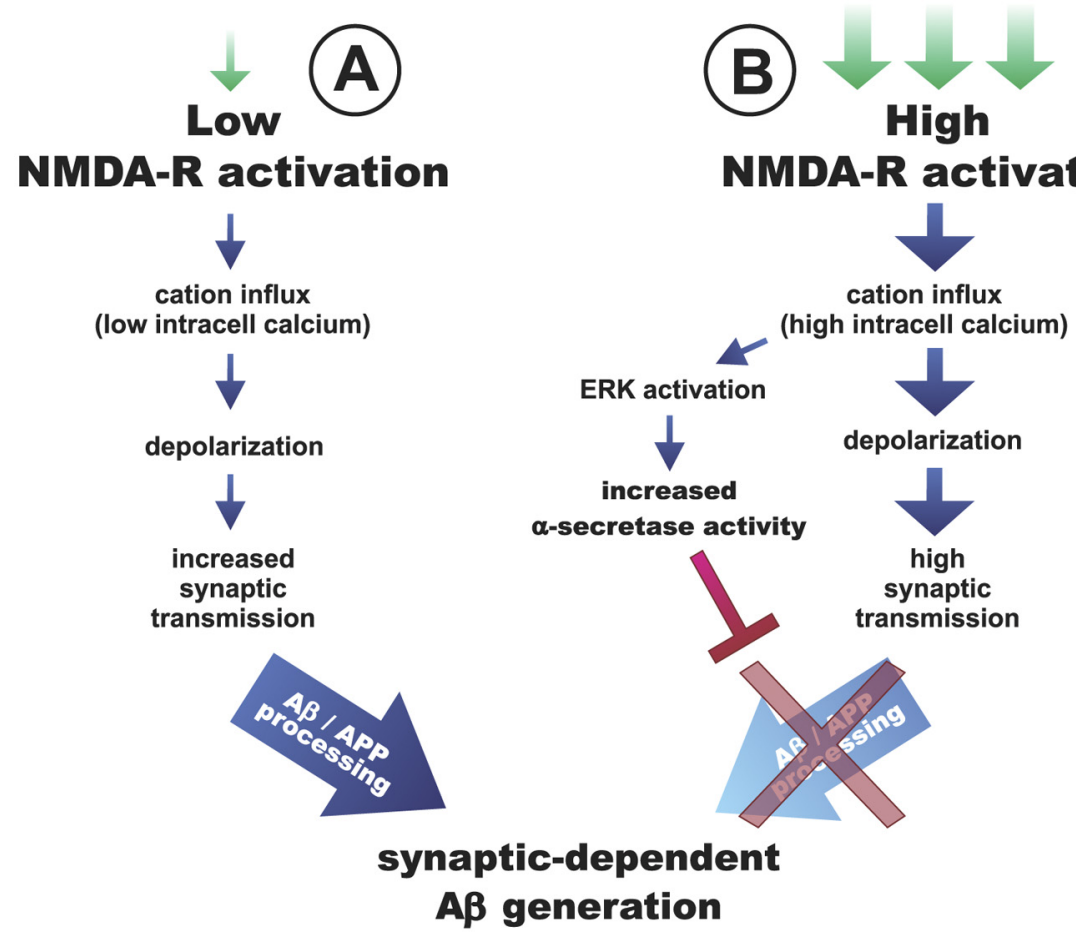

Figure 7. Model of synaptic mechanisms that regulate $A \beta$ metabolism. $A$, Synaptic $A \beta$ generation: NMDA infusion into the hippocampus increases synaptic activity and elevates $A \beta$ generation and then secretion. APP processing progresses normally here, but at an increased rate. $B$, Synaptic modulation of APP processing: high levels of NMDA-R activation cause calcium influx into the neuron, which activates the ERK signaling cascade. ERK enhances $\alpha$-secretase cleavage of APP, thus reducing APP processing into $A \beta$. The balance between synaptic generation and APP processing determines whether overall ISF A $\beta$ levels increase or decrease, respectively.

APP processing mechanisms depending on the dose of NMDA used and the developmental state in each culture model.

It appears that NMDA-Rs, specifically during prolonged activation of extrasynaptic receptors, can induce changes in APP transcription shifting from APP695 transcripts to more amyloidogenic APPs that contain a Kunitz protease inhibitor (APPKPI) domain (Bordji et al., 2010). While transcriptional changes may occur in some systems, it is unlikely to be playing a role in our study given that the PS1APP mice we used overexpress an APP695 transgene that is not affected by normal APP transcriptional regulation. Our administration of NMDA in these studies was relatively short-lived (hours), however, so it is possible that prolonged dosing would have recruited changes in transcription.

Calcium entry through NMDA-Rs can act as a second messenger. Influx of calcium triggers a variety of signaling pathways, including protein kinase $\mathrm{C}(\mathrm{PKC})$, protein kinase $\mathrm{A}(\mathrm{PKA})$, and calcium/calmodulin-dependent kinase II (CaMKII), all of which can activate ERK and may regulate some facet of $A \beta$ metabolism (Chandler et al., 2001; Kawasaki et al., 2004). Alternatively, for NMDA-Rs that contain a NR2B subunit, calcium can cause dissociation of factors physically associated with the receptor, which leads to direct activation of the ERK signaling cascade (Krapivinsky et al., 2003; Kim et al., 2005). Importantly, inhibition of NR2Bcontaining receptors only marginally affected $\mathrm{A} \beta$ metabolism in our studies, suggesting that NR2B plays a relatively minor role in regulation of $A \beta$ metabolism. The subcellular localization of NMDA-Rs or their subunit composition may still play critical roles in regulating $\mathrm{A} \beta$ levels, however, in that these factors can influence when and how ERK activity is regulated in neurons (Kim et al., 2005; Ivanov et al., 2006).

\section{ERK signaling and $\mathrm{A} \beta$ production}

Activated pERK is elevated in the brains and CSF of AD patients (Perry et al., 1999; Klafki et al., 2009). These studies propose that ERK activation is a consequence of $\mathrm{AD}$-related changes, including oxidative stress and inflammation; however, the possibility cannot be discounted that ERK activity also contributes to $\mathrm{AD}$ progression. Several studies demonstrate that ERK can modulate APP processing, suggesting that this signaling pathway may be a direct factor in AD processes. Decreasing $\beta$-secretase or $\gamma$-secretase cleavage or increasing $\alpha$-secretase cleavage of APP all can reduce A $\beta$ generation. Similar to our study, ERK has been found to increase $\alpha$-secretase cleavage of APP (Kojro et al., 2006) as well as reduce $\gamma$-secretase activity. Inhibition of ERK increases $\gamma$-secretase activity in vitro and in vivo (Kim et al., 2006). Activated pERK phosphorylates a component of the $\gamma$-secretase complex, nicastrin, which appears to reduce cleavage activity (Kim et al., 2006; Tung et al., 2008). While our data show that PS1 protein levels are elevated following NMDA-R antagonism (Fig. 6D), given that PS1 is not the ratelimiting component of the complex, it is unclear whether this would elevate $\gamma$-secretase activity in vivo. These alterations in $\alpha$-secretase and $\gamma$-secretase both could result in reduced APP 
processing into $A \beta$; however, whether ERK also induces other changes that impact $\mathrm{A} \beta$ metabolism is unknown.

\section{Use of ERK signaling as a treatment strategy for AD}

NMDA-R agonists are unlikely to be a viable chronic therapy for $\mathrm{AD}$ given the role of these receptors in neuronal transmission, synaptic plasticity, and excitotoxicity. However, it is ultimately ERK signaling that is responsible for suppression of $A \beta$ levels; NMDA-R activation is only one means by which this can occur. It is possible that activation of ERK via other means could be used to depress $A \beta$ levels therapeutically. Calcium influx through NMDA-Rs has been shown to activate ERK (Bading and Greenberg, 1991; Krapivinsky et al., 2003). The cellular context in which ERK is activated dictates the downstream effects of this kinase; thus, not all ERK activators may lower $\mathrm{A} \beta$ levels to a similar extent (Pouysségur et al., 2002). Dopamine, metabotropic glutamate, and serotonin neurotransmitter receptors have also been linked to ERK activation [for review, see Sweatt (2001) and Cowen (2007)], as well as a wide range of other molecules, such as growth factors, integrins, and neurosteroids. In this study, only a subset of these receptors lead to depressed $\mathrm{A} \beta$ levels. There are currently several drugs, including some approved by the FDA for use in humans, that target receptors that may be capable of activating ERK in vivo. Such drugs may contribute to disease risk by altering $A \beta$ levels over a lifetime. Compounds that activate ERK within the brain may also be candidate preventative or therapeutic agents capable of lowering $\mathrm{A} \beta$ and reducing $\mathrm{AD}$ plaque pathogenesis or growth.

\section{References}

Bading H, Greenberg ME (1991) Stimulation of protein tyrosine phosphorylation by NMDA receptor activation. Science 253:912-914.

Basta-Kaim A, Budziszewska B, Jaworska-Feil L, Leśkiewicz M, Tetich M, Otczyk M, Kubera M, Lasoń W (2007) Effects of neurosteroids on glucocorticoid receptor-mediated gene transcription in LMCAT cells-a possible interaction with psychotropic drugs. Eur Neuropsychopharmacol 17:37-45.

Bordji K, Becerril-Ortega J, Nicole O, Buisson A (2010) Activation of extrasynaptic, but not synaptic, NMDA receptors modifies amyloid precursor protein expression pattern and increases amyloid- $\beta$ production. J Neurosci 30:15927-15942.

Boulton TG, Cobb MH (1991) Identification of multiple extracellular signal-regulated kinases (ERKs) with antipeptide antibodies. Cell Regul 2:357-371.

Caccamo A, Oddo S, Billings LM, Green KN, Martinez-Coria H, Fisher A, LaFerla FM (2006) M1 receptors play a central role in modulating ADlike pathology in transgenic mice. Neuron 49:671-682.

Chandler LJ, Sutton G, Dorairaj NR, Norwood D (2001) N-Methyl D-aspartate receptor-mediated bidirectional control of extracellular signal-regulated kinase activity in cortical neuronal cultures. J Biol Chem 276:2627-2636.

Cirrito JR, May PC, O'Dell MA, Taylor JW, Parsadanian M, Cramer JW, Audia JE, Nissen JS, Bales KR, Paul SM, DeMattos RB, Holtzman DM (2003) In vivo assessment of brain interstitial fluid with microdialysis reveals plaque-associated changes in amyloid- $\beta$ metabolism and half-life. J Neurosci 23:8844-8853.

Cirrito JR, Yamada KA, Finn MB, Sloviter RS, Bales KR, May PC, Schoepp DD, Paul SM, Mennerick S, Holtzman DM (2005) Synaptic activity regulates interstitial fluid amyloid-beta levels in vivo. Neuron 48:913-922.

Cirrito JR, Kang JE, Lee J, Stewart FR, Verges DK, Silverio LM, Bu G, Mennerick S, Holtzman DM (2008) Endocytosis is required for synaptic activity-dependent release of amyloid-beta in vivo. Neuron 58:42-51.

Cowen DS (2007) Serotonin and neuronal growth factors-a convergence of signaling pathways. J Neurochem 101:1161-1171.

Davis AA, Fritz JJ, Wess J, Lah JJ, Levey AI (2010) Deletion of M1 muscarinic acetylcholine receptors increases amyloid pathology in vitro and in vivo. J Neurosci 30:4190-4196.

Duva MA, Tomkins EM, Moranda LM, Kaplan R, Sukhaseum A, Jimenez A,
Stanley BG (2001) Reverse microdialysis of N-methyl-D-aspartic acid into the lateral hypothalamus of rats: effects on feeding and other behaviors. Brain Res 921:122-132.

Fazeli MS, Breen K, Errington ML, Bliss TV (1994) Increase in extracellular NCAM and amyloid precursor protein following induction of long-term potentiation in the dentate gyrus of anaesthetized rats. Neurosci Lett 169:77-80.

Gordon-Krajcer W, Salińska E, Lazarewicz JW (2002) N-Methyl-daspartate receptor-mediated processing of beta-amyloid precursor protein in rat hippocampal slices: in vitro-superfusion study. Folia Neuropathol 40:13-17.

Gouras GK, Tsai J, Naslund J, Vincent B, Edgar M, Checler F, Greenfield JP, Haroutunian V, Buxbaum JD, Xu H, Greengard P, Relkin NR (2000) Intraneuronal Abeta42 accumulation in human brain. Am J Pathol 156:15-20.

Grimwood S, Wafford KA, Macaulay A, Hutson PH (2002) N-Methyl-Daspartate receptor subtype-selectivity of homoquinolinate: an electrophysiological and radioligand binding study using both native and recombinant receptors. J Neurochem 82:794-800.

Hardy J (2006) A hundred years of Alzheimer's disease research. Neuron 52:3-13.

Harris JA, Devidze N, Verret L, Ho K, Halabisky B, Thwin MT, Kim D, Hamto P, Lo I, Yu GQ, Palop JJ, Masliah E, Mucke L (2010) Transsynaptic progression of amyloid-beta-induced neuronal dysfunction within the entorhinal-hippocampal network. Neuron 68:428-441.

Hetman M, Kanning K, Cavanaugh JE, Xia Z (1999) Neuroprotection by brain-derived neurotrophic factor is mediated by extracellular signalregulated kinase and phosphatidylinositol 3-kinase. J Biol Chem 274:22569-22580.

Hock C, Maddalena A, Raschig A, Müller-Spahn F, Eschweiler G, Hager K, Heuser I, Hampel H, Müller-Thomsen T, Oertel W, Wienrich M, Signorell A, Gonzalez-Agosti C, Nitsch RM (2003) Treatment with the selective muscarinic $\mathrm{ml}$ agonist talsaclidine decreases cerebrospinal fluid levels of A beta 42 in patients with Alzheimer's disease. Amyloid 10:1-6.

Hoey SE, Williams RJ, Perkinton MS (2009) Synaptic NMDA receptor activation stimulates $\alpha$-secretase amyloid precursor protein processing and inhibits amyloid- $\beta$ production. J Neurosci 29:4442-4460.

Huettner JE, Bean BP (1988) Block of N-methyl-D-aspartate-activated current by the anticonvulsant MK-801: selective binding to open channels. Proc Natl Acad Sci U S A 85:1307-1311.

Ivanov A, Pellegrino C, Rama S, Dumalska I, Salyha Y, Ben-Ari Y, Medina I (2006) Opposing role of synaptic and extrasynaptic NMDA receptors in regulation of the extracellular signal-regulated kinases (ERK) activity in cultured rat hippocampal neurons. J Physiol 572:789-798.

Kamenetz F, Tomita T, Hsieh H, Seabrook G, Borchelt D, Iwatsubo T, Sisodia S, Malinow R (2003) APP processing and synaptic function. Neuron 37:925-937.

Kang JE, Lim MM, Bateman RJ, Lee JJ, Smyth LP, Cirrito JR, Fujiki N, Nishino S, Holtzman DM (2009) Amyloid-beta dynamics are regulated by orexin and the sleep-wake cycle. Science 326:1005-1007.

Kawasaki Y, Kohno T, Zhuang ZY, Brenner GJ, Wang H, Van Der Meer C, Befort K, Woolf CJ, Ji RR (2004) Ionotropic and metabotropic receptors, protein kinase A, protein kinase $\mathrm{C}$, and Src contribute to C-fiberinduced ERK activation and cAMP response element-binding protein phosphorylation in dorsal horn neurons, leading to central sensitization. J Neurosci 24:8310-8321.

Kim J, Castellano JM, Jiang H, Basak JM, Parsadanian M, Pham V, Mason SM, Paul SM, Holtzman DM (2009) Overexpression of low-density lipoprotein receptor in the brain markedly inhibits amyloid deposition and increases extracellular A beta clearance. Neuron 64:632-644.

Kim MJ, Dunah AW, Wang YT, Sheng M (2005) Differential roles of NR2Aand NR2B-containing NMDA receptors in Ras-ERK signaling and AMPA receptor trafficking. Neuron 46:745-760.

Kim SK, Park HJ, Hong HS, Baik EJ, Jung MW, Mook-Jung I (2006) ERK1/2 is an endogenous negative regulator of the gamma-secretase activity. FASEB J 20:157-159.

Klafki HW, Lewczuk P, Kamrowski-Kruck H, Maler JM, Müller K, Peters O, Heuser I, Jessen F, Popp J, Frölich L, Wolf S, Prinz B, Luckhaus C, Schröder J, Pantel J, Gertz HJ, Kölsch H, Müller BW, Esselmann H, Bibl M, et al. (2009) Measurement of ERK $1 / 2$ in CSF from patients with neuropsychiatric disorders and evidence for the presence of the activated form. J Alzheimers Dis 18:613-622. 
Köhr G (2006) NMDA receptor function: subunit composition versus spatial distribution. Cell Tissue Res 326:439-446.

Kojro E, Postina R, Buro C, Meiringer C, Gehrig-Burger K, Fahrenholz F (2006) The neuropeptide PACAP promotes the alpha-secretase pathway for processing the Alzheimer amyloid precursor protein. FASEB J 20: $512-514$.

Koo EH, Squazzo SL (1994) Evidence that production and release of amyloid beta-protein involves the endocytic pathway. J Biol Chem 269: 17386-17389.

Krapivinsky G, Krapivinsky L, Manasian Y, Ivanov A, Tyzio R, Pellegrino C, Ben-Ari Y, Clapham DE, Medina I (2003) The NMDA receptor is coupled to the ERK pathway by a direct interaction between NR2B and RasGRF1. Neuron 40:775-784.

Kurino M, Fukunaga K, Ushio Y, Miyamoto E (1995) Activation of mitogen-activated protein kinase in cultured rat hippocampal neurons by stimulation of glutamate receptors. J Neurochem 65:1282-1289.

Lammich S, Kojro E, Postina R, Gilbert S, Pfeiffer R, Jasionowski M, Haass C, Fahrenholz F (1999) Constitutive and regulated alpha-secretase cleavage of Alzheimer's amyloid precursor protein by a disintegrin metalloprotease. Proc Natl Acad Sci U S A 96:3922-3927.

Lesné S, Ali C, Gabriel C, Croci N, MacKenzie ET, Glabe CG, Plotkine M, Marchand-Verrecchia C, Vivien D, Buisson A (2005) NMDA receptor activation inhibits $\alpha$-secretase and promotes neuronal amyloid- $\beta$ production. J Neurosci 25:9367-9377.

Lomakin A, Teplow DB, Kirschner DA, Benedek GB (1997) Kinetic theory of fibrillogenesis of amyloid beta-protein. Proc Natl Acad Sci U S A 94:7942-7947.

Marcello E, Gardoni F, Mauceri D, Romorini S, Jeromin A, Epis R, Borroni B, Cattabeni F, Sala C, Padovani A, Di Luca M (2007) Synapse-associated protein-97 mediates $\alpha$-secretase ADAM10 trafficking and promotes its activity. J Neurosci 27:1682-1691.

Meyer-Luehmann M, Stalder M, Herzig MC, Kaeser SA, Kohler E, Pfeifer M, Boncristiano S, Mathews PM, Mercken M, Abramowski D, Staufenbiel M, Jucker M (2003) Extracellular amyloid formation and associated pathology in neural grafts. Nat Neurosci 6:370-377.

Nitsch RM, Deng M, Tennis M, Schoenfeld D, Growdon JH (2000) The selective muscarinic M1 agonist AF102B decreases levels of total Abeta in cerebrospinal fluid of patients with Alzheimer's disease. Ann Neurol 48:913-918.

Olney JW, Sharpe LG (1969) Brain lesions in an infant rhesus monkey treated with monsodium glutamate. Science 166:386-388.

Patneau DK, Mayer ML (1990) Structure-activity relationships for amino acid transmitter candidates acting at $N$-methyl-D-aspartate and quisqualate receptors. J Neurosci 10:2385-2399.

Perry G, Roder H, Nunomura A, Takeda A, Friedlich AL, Zhu X, Raina AK, Holbrook N, Siedlak SL, Harris PL, Smith MA (1999) Activation of neuronal extracellular receptor kinase (ERK) in Alzheimer disease links oxidative stress to abnormal phosphorylation. Neuroreport 10:2411-2415.

Pouysségur J, Volmat V, Lenormand P (2002) Fidelity and spatio-temporal control in MAP kinase (ERKs) signalling. Biochem Pharmacol 64: $755-763$.

Savonenko AV, Xu GM, Price DL, Borchelt DR, Markowska AL (2003) Normal cognitive behavior in two distinct congenic lines of transgenic mice hyperexpressing mutant APP SWE. Neurobiol Dis 12:194-211.

Sweatt JD (2001) The neuronal MAP kinase cascade: a biochemical signal integration system subserving synaptic plasticity and memory. J Neurochem 76:1-10.

Tung YT, Hsu WM, Wang BJ, Wu SY, Yen CT, Hu MK, Liao YF (2008) Sodium selenite inhibits gamma-secretase activity through activation of ERK. Neurosci Lett 440:38-43.

Wei W, Nguyen LN, Kessels HW, Hagiwara H, Sisodia S, Malinow R (2010) Amyloid beta from axons and dendrites reduces local spine number and plasticity. Nat Neurosci 13:190-196.

Xia Z, Dudek H, Miranti CK, Greenberg ME (1996) Calcium influx via the NMDA receptor induces immediate early gene transcription by a MAP kinase/ERK-dependent mechanism. J Neurosci 16:5425-5436.

Yan P, Bero AW, Cirrito JR, Xiao Q, Hu X, Wang Y, Gonzales E, Holtzman DM, Lee JM (2009) Characterizing the appearance and growth of amyloid plaques in APP/PS1 mice. J Neurosci 29:10706-10714.

Zhang YW, Thompson R, Zhang H, Xu H (2011) APP processing in Alzheimer's disease. Mol Brain 4:3. 